\title{
Monitoring the Charcoal Furnace Control System of Coconut Shell Waste Treatment Becoming Charcoal with ATMega 328P Microcontroller
}

\author{
Maureen Langue \\ Electrical Engineering Dept \\ Manado State Polytechnic \\ North Sulawesi - Indonesia
}

\author{
Sukandar Sawidin \\ Information Technology Dept \\ Manado State Polytechnic \\ North Sulawesi - Indonesia
}

\author{
Jusuf L. Mappadang \\ Electrical Engineering Dept \\ Manado State Polytechnic \\ North Sulawesi - Indonesia
}

\begin{abstract}
Coconut plants is the one of potential commodities that are classified as strategic hard/annual plantation commodity. Demand of the coconut plants tend to increase each time along with development of science and technology that increase rapidly these days, especially in the computerized technology field that is real with the existing of computer device which is working automatically then will be designed with integrated control using microcontroller.

The testing result on the control system of the charcoal furnace indicates that the system works by the design. Testing control of servo motor to setting up the size of flame on the gas stove set by servo motor to open/close the regulator on LPG gas.

The testing on the charcoal furnace control Thermocouple Type $\mathrm{K}$ signal sensor detects temperature on the charcoal furnace during the combustion of the coconut shell then processing by microcontroller and will be displayed on LCD and monitoring on PC with LabView application program.

Testing process with the coconut shell that burned in the charcoal furnace for $23 \mathrm{~kg}$ produce charcoal for $8.75 \mathrm{~kg}$, meanwhile the room temperature average during the testing process is $30.46^{\circ} \mathrm{C}$ and the maximum temperature of charcoal furnace is $215^{\circ} \mathrm{C}$.
\end{abstract}

\section{General Terms}

Personal Computer, Control System and LabView.

\section{Keywords}

Charcoal Furnace, Microcontroller, servo motor, Sensor Thermocouple

\section{INTRODUCTION}

Indonesia is the country that has coconut wide plantation number one in the world. The Indonesia coconut wide plantation is about 3.712 million hectare $(31.4 \%$ of the wide coconut plantation in the world) with the produce coconut for more or less 12.915 billion pieces $(24.4 \%$ of world production). The weight of coconut shell reach about $12 \%$ of coconut weight. By the average weight of a piece of coconut $1.5 \mathrm{~kg}$, then Indonesia coconut shell potential reach about 2324.7 million tons/year (Ditjenbun, 2007). [4,7,10]

The increase of oil fuel price especially the kerosene make people look for another alternative to cook. One of the choice as fuel is charcoal from coconut shell. $[1,7,10]$

In the North Sulawesi, coconut shell to make charcoal can find easily because in this region there are many coconut plantation. The charcoal of coconut shell is the product that is produced from incomplete combustion of coconut shell. As a fuel the charcoal is more profit than firewood. The charcoal produce higher combustion heat and less smoke until the cook process become faster. [4,5]

Besides for being used directly, the charcoal of coconut shell also can be pounded then condensed back and printed become briquet in various shape. Briquet is obviously more practice and use easily than firewood. Charcoal can be further processed to be active charcoal or as material charger and dyes in rubber and plastic industry. The big potential business of the charcoal of coconut shell is one of the business opportunity which has fine prospect for small trade.[6,9]

\section{LITERATURE REVIEW}

\subsection{Microcontroller ATMEGA 328P}

Arduino Uno microcontroller ATMEGA 328P is an electronic circuit that is open source, and have the hardware and software that is easy to use. Arduino can recognize the surrounding environment through a variety of sensors and can control lights, motors, and various other types of actuators. Arduino has many types, including Arduino Uno, Arduino Mega 2560, Arduino Fio, and others. [2,3]

\subsection{LabVIEW (Laboratory Virtual Instrument Engineering Workbench)}

LabVIEW is a graphical programming language using the icon that is connected by a line (wire) to create a LabVIEW application.

LabVIEW or Laboratory Virtual Instrument Engineering Workbench is a graphical programming language that has been used by industry, academia, and government lab as a standard for data software aquisisi and control instrumentation. LabVIEW is ideal for the application of science and engineering. $[3,8]$

LabVIEW program is called Virtual instruments or VI's, because of the shape mimics the look and operation of the physical form of an instrument such as an oscilloscope and multimeter. Every VI uses functions use interface or input from other sources and display the information or move it to other files or other computers. [2,8]

LabVIEW includes various additions and improvements to mathematics, signal processing, and analysis than previous LabVIEW.[8]

\subsection{Thermocouple Sensor}

Thermocouple consists essentially of a pair of hot and cold transducer connected and merged together, where there are 
differences that arise between the connection with the reference junction which serves as a comparison.

Basically thermocouple consists of two metal wire conductors of different types and coupled ends. One type of metallic conductors contained in Thermocouples will serve as a reference to a constant temperature (fixed) while the other one as metallic conductors that detect heat. $[5,6]$

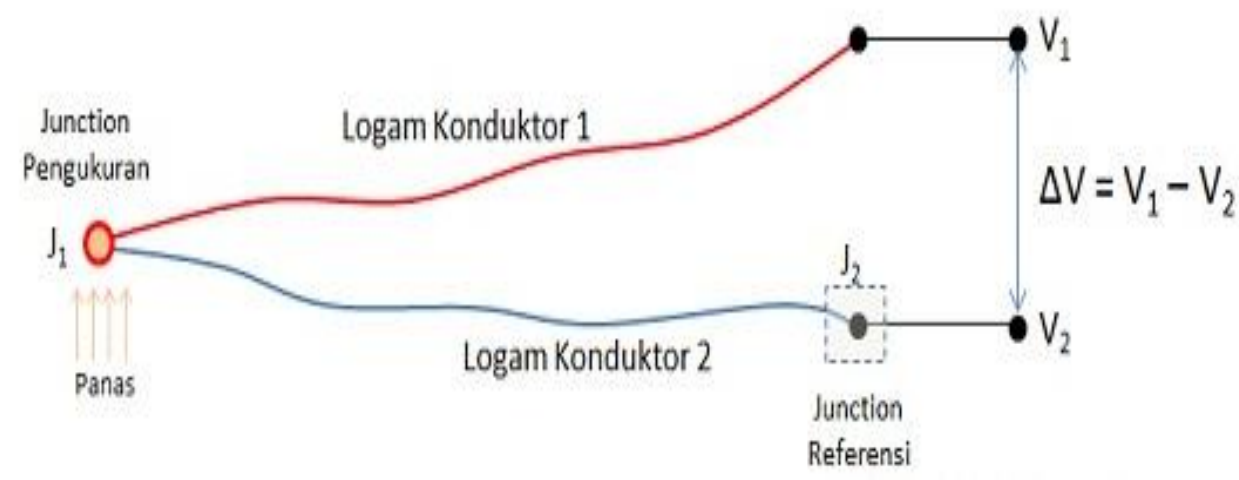

Pic 1. How it Works Thermocouples

Based on pic 1, when the two intersections or Junction have the same temperature, then the potential difference or voltage electricity through the two intersections is "ZERO" or V1 = V2. However, when the intersection is connected in series given the hot temperatures or connected to the measurement object, there will be a temperature difference between two intersections which then produces an electric voltage whose value is proportional to the temperature of the heat it receives or V1 - V2. Electricity generated voltage is generally about 1 $\mu \mathrm{V}-70 \mu \mathrm{V}$ at each degree Celsius. $[4,5,6]$

\section{METHODOLOGY}

In this research use the design method, which started from make a charcoal furnace prototype with the size $600 \mathrm{~mm}$ length, $600 \mathrm{~mm}$ width, and $1000 \mathrm{~mm}$ height, then make the temperature control system and servo motor control to adjust the regulator on the LPG gas tube with the requirements in the process of charcoal furnace. After the system made complete then the coconut shell to be put into charcoal furnace, then do the process of combustion of coconut shell become charcoal and taking the temperature data by monitoring on $\mathrm{PC}$ use the LCD and LabView.

\section{RESULT AND DISCUSSION}

4.1 Draft Research Model

Design of control system monitoring covers: prototype design of charcoal furnace, software and hardware. Design system will forming a control system of temperature and servomotor. The controlling is done by controlling the size of temperature and regulator on the LPG tube.

The prototype that will be made is the prototype from monitoring control system for charcoal furnaces. The prototype that will be made as the Picture 2 .

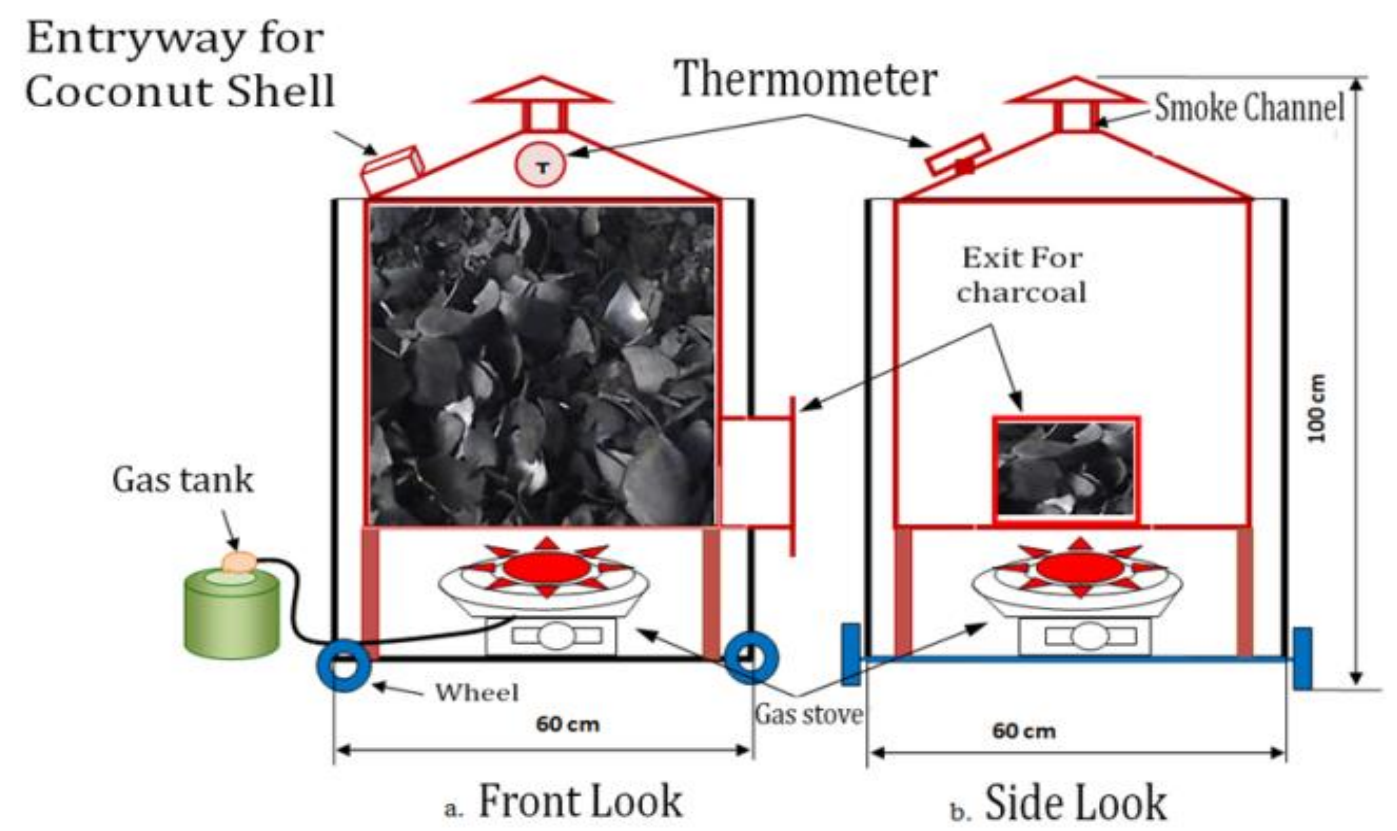

Pic.2 Design prototype of Charcoal Furnaces 


\subsection{Diagram Block System}

The easiest to meet the requirements of writing format is use this document as template. Then type your text in it.

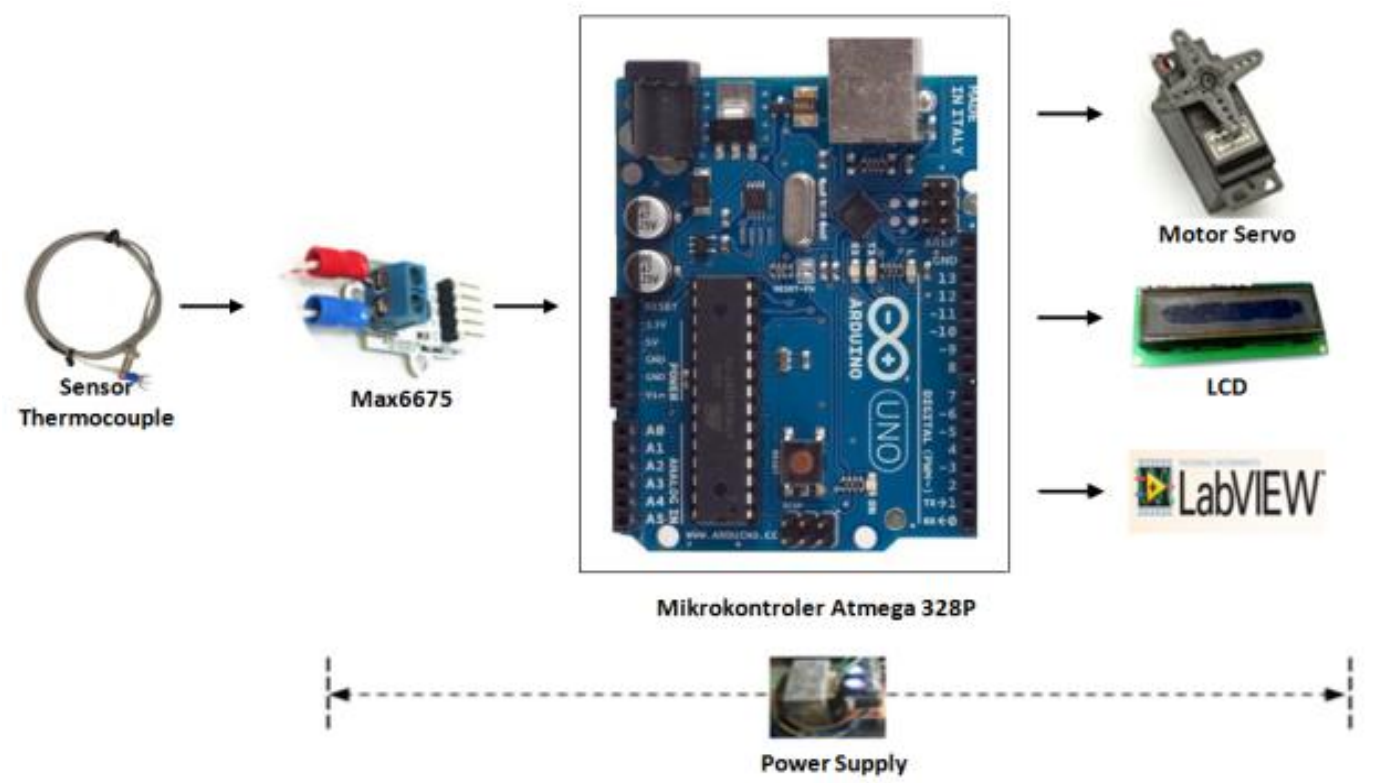

Pic. 3 Diagram Block the control system of charcoal Furnaces

Note:

1. The power supply to supply Input / Output equipment and control device of microcontroller Atmega 328P with the voltage $5 \mathrm{Vdc}$.

2. Thermocouple sensor and driver Max6675 as the microcontroller input to detect temperature in the charcoal furnaces.

3. Microcontroller Atmega 328P as control centre of the charcoal furnaces control system receive the signal that has given, processed then the output to display LCD, PC Monitoring with LabView.
4. Servo motor as the flame control of gas stove by adjust regulator on the LPG gas tube.

5. The LCD as output display of temperature signal.

6. Laptop / Desktop use for system monitoring with LabView.

\subsection{Control System Draft of Charcoal Furnace with LCD and LabView}

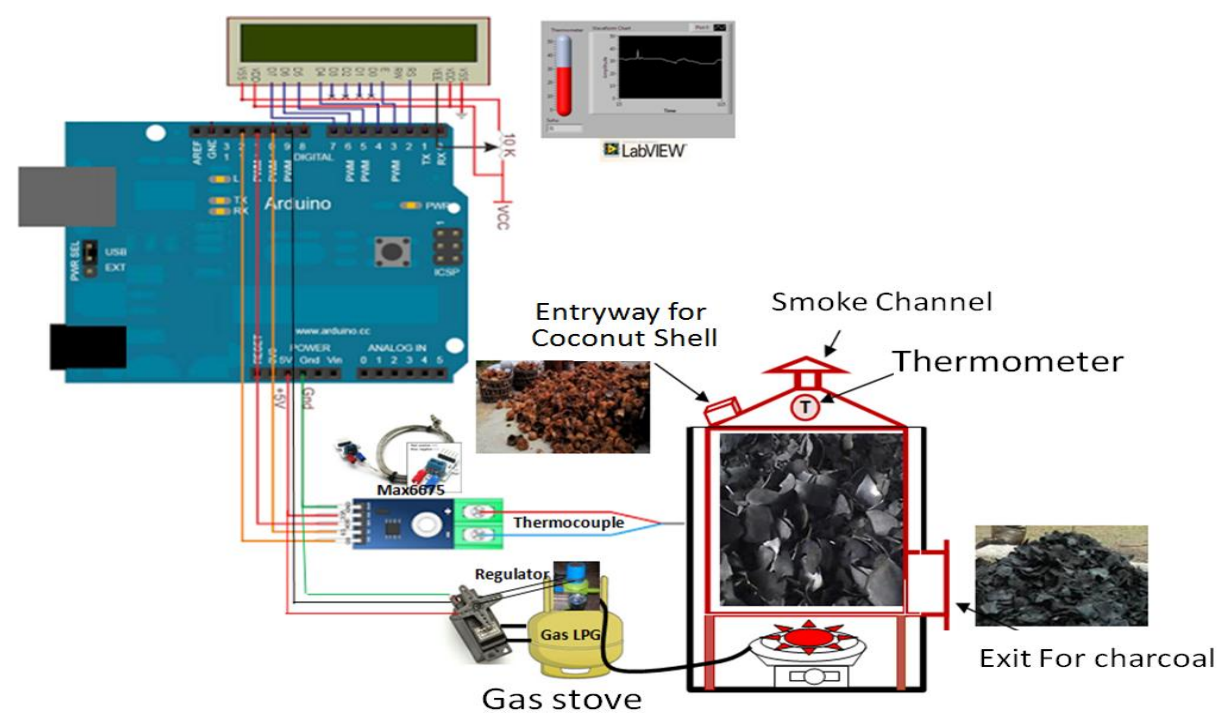

Pic.4 Monitoring Control System of Charcoal Furnace 
On picture 4, Thermocouple sensor signal Type K will detect the temperature on the Charcoal Furnace when the combustion of coconut shell will be processed by microcontroller then will be displayed on LCD and monitoring on PC with the LabView application program.

The size of flame on the gas stove adjust by servo motor to open/close the regulator on LPG gas.

\subsection{System Testing}

The test is done to find out system performance of design result is it working well in accordance with system
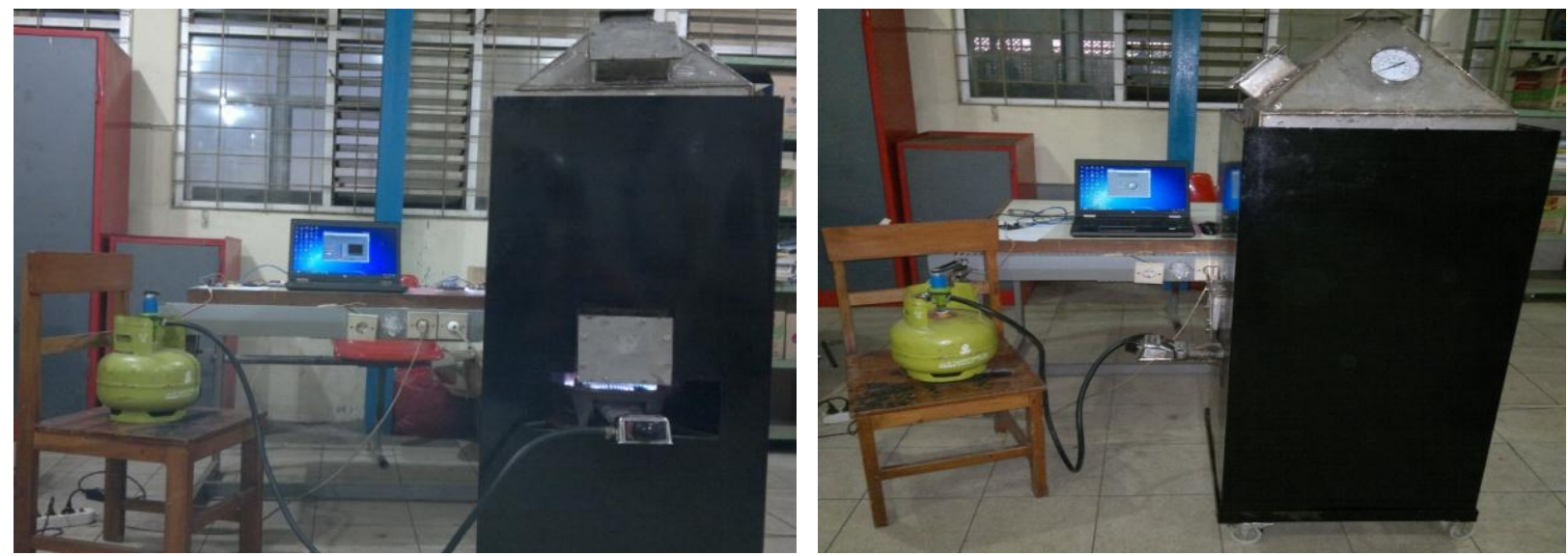

Pic. 5 Control System Furnaces Charcoal

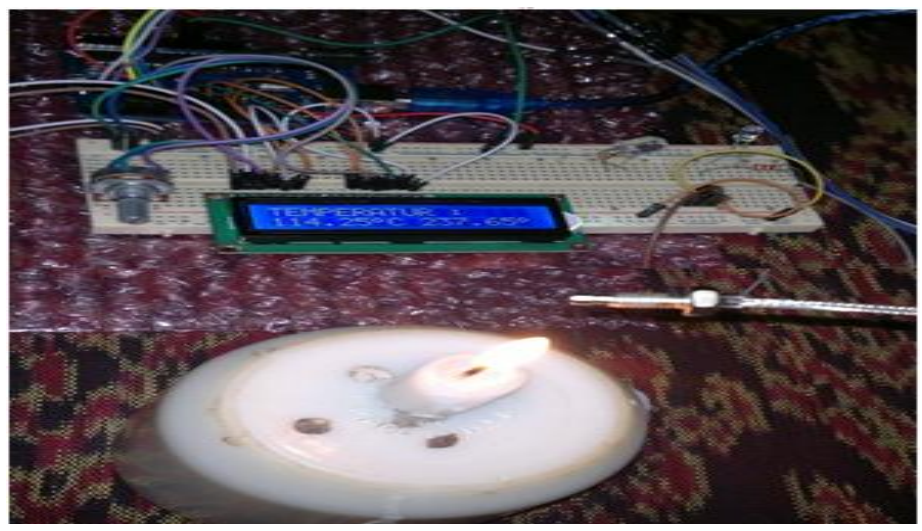

Pic.6 Testing Thermocouple Sensor and LCD

Figure 6. Shows Testing Process And Data retrieval termocouple Temperature sensor, Process Testing Where do

heat sensor is with way termocouple then the results are displayed On LCD.

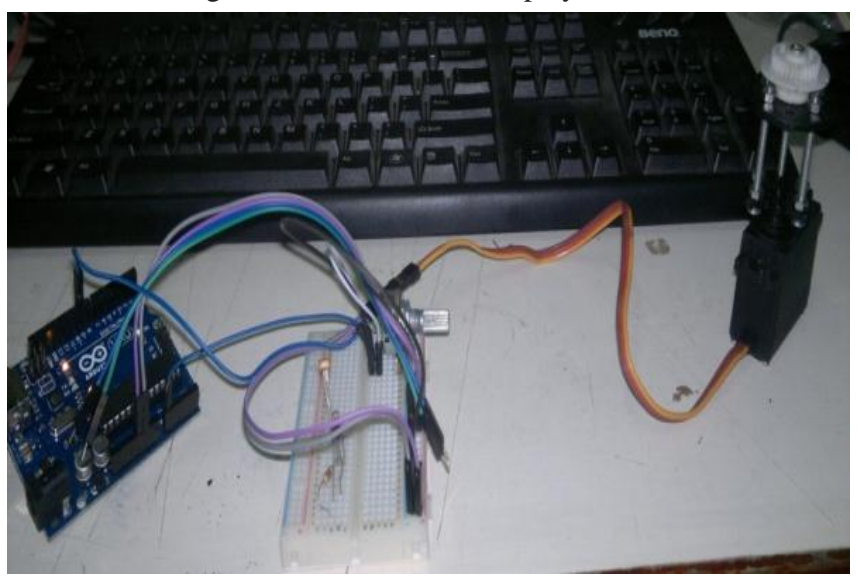

Pic 7. Testing servo motor for set Regulator Gas LPG 
Figure 7. Shows the process of testing a program built into the microcontroller arduino uno, for setting the servo motor, servo motor control where the process is done with a slew via potentiometer.

After the stages of hardware and software design has done then tested the control system of charcoal furnace and system monitoring on PC as follows:

\section{A. Monitoring Testing Control Servo Motor}

When it is run we twist the Dial to the left or right to stir servo motor that connected to LPG gas to adjust the size of flame during the combustion process of coconut shell becoming charcoal. Monitoring Control Servo Motor with LabView displayed with Figure 8.

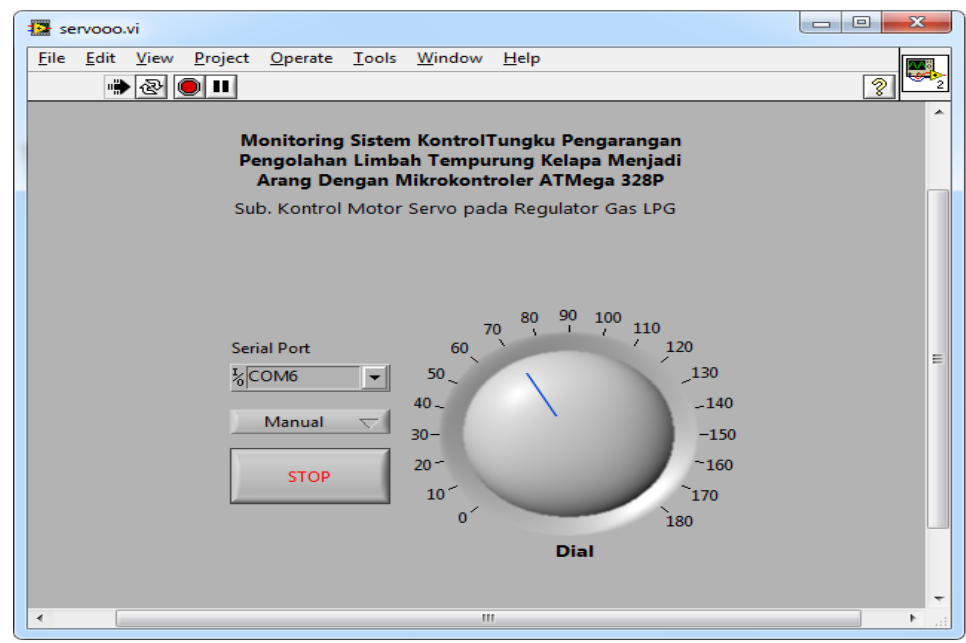

Pic.8. Monitoring Control Servo Motor with LabView

\section{B. Monitoring Testing Thermocouple Sensor}

When it is run the temperature sensor will detect the charcoal furnace temperature when the Set point that inputted $=200^{\circ} \mathrm{C}$ on the Front Panel LabView, and when the temperature

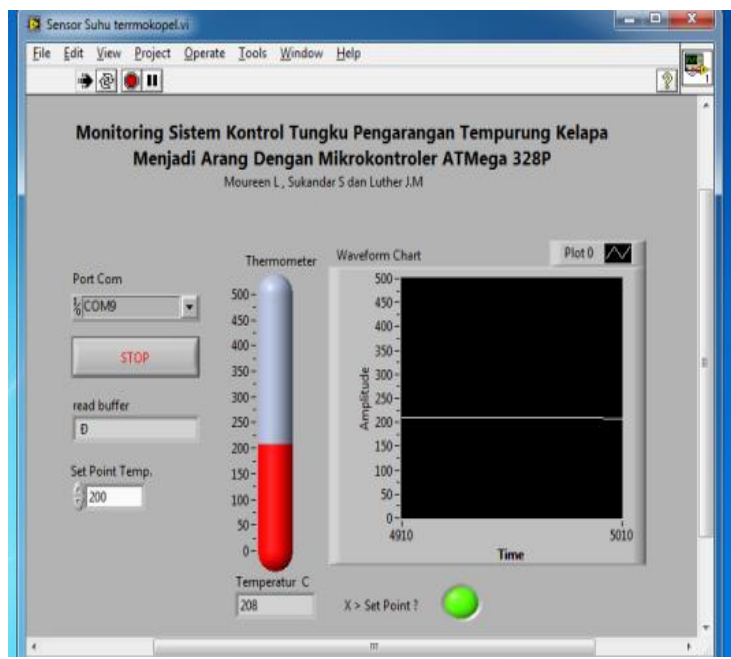

Pic. a. Temperature $68{ }^{\circ} \mathrm{C}$ parameter that detected exceed the temperature set point then led indicator will light. Temperature Monitoring With LabView displayed with Figure 9.

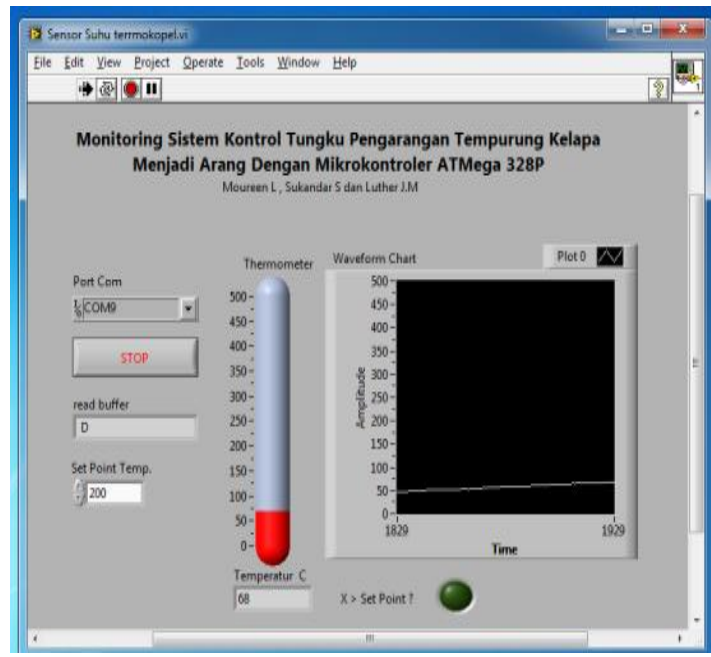

Pic. b. Temperature $208{ }^{0} \mathrm{C}$

Pic. 9. Temperature MonitoringWith LabView

\section{ANALYSIS TEST RESULTS}

From the observations of researchers to observe and record the test results and gain the data listed in Table 1 and a comparison chart between room temperature with the temperature in the furnace shown in Figure 10, which is a representation of Table 1. From the results of tests performed, as shown in Table 1, data showed that the process of burning coconut shells at the time of surgery for 150 minutes, to room temperature $30.7^{\circ} \mathrm{C}$ and the temperature in the furnace at $200^{\circ} \mathrm{C}$ (as setting the temperature set point), obtained comparable data density shell oil before and after the combustion process. Where at the time prior to combustion, density is $23 \mathrm{~kg}$ coconut shell and after the combustion process (after being charcoal), obtained weighs $8.75 \mathrm{~kg}$. 
Table 1. Measurement data of room temperature and charcoal furnace temperature on the testing tools.

\begin{tabular}{|c|c|c|c|c|c|}
\hline No & $\begin{array}{c}\text { Time } \\
\text { (minute) }\end{array}$ & $\begin{array}{l}\text { Room } \\
\text { Temp. } \\
\left({ }^{\circ} \mathrm{C}\right)\end{array}$ & $\begin{array}{c}\text { Furnace } \\
\text { Temp. } \\
\left({ }^{\circ} \mathrm{C}\right)\end{array}$ & $\begin{array}{c}\text { Massa } \\
\text { coconut } \\
\text { shells }(\mathrm{kg})\end{array}$ & $\begin{array}{c}\text { Massa } \\
\text { coconut shel } \\
\text { charcoal }(\mathrm{kg})\end{array}$ \\
\hline 1 & 0 & 30.1 & 25 & \multirow{12}{*}{23} & \multirow{12}{*}{8.75} \\
\hline 2 & 15 & 30.1 & 55 & & \\
\hline 3 & 30 & 30.2 & 100 & & \\
\hline 4 & 45 & 30.3 & 110 & & \\
\hline 5 & 60 & 30.4 & 130 & & \\
\hline 6 & 75 & 30.5 & 170 & & \\
\hline 7 & 90 & 30.5 & 200 & & \\
\hline 8 & 105 & 30.6 & 210 & & \\
\hline 9 & 120 & 30.6 & 215 & & \\
\hline 10 & 135 & 30.7 & 205 & & \\
\hline 11 & 150 & 30.7 & 200 & & \\
\hline 12 & 165 & 30.8 & 195 & & \\
\hline
\end{tabular}

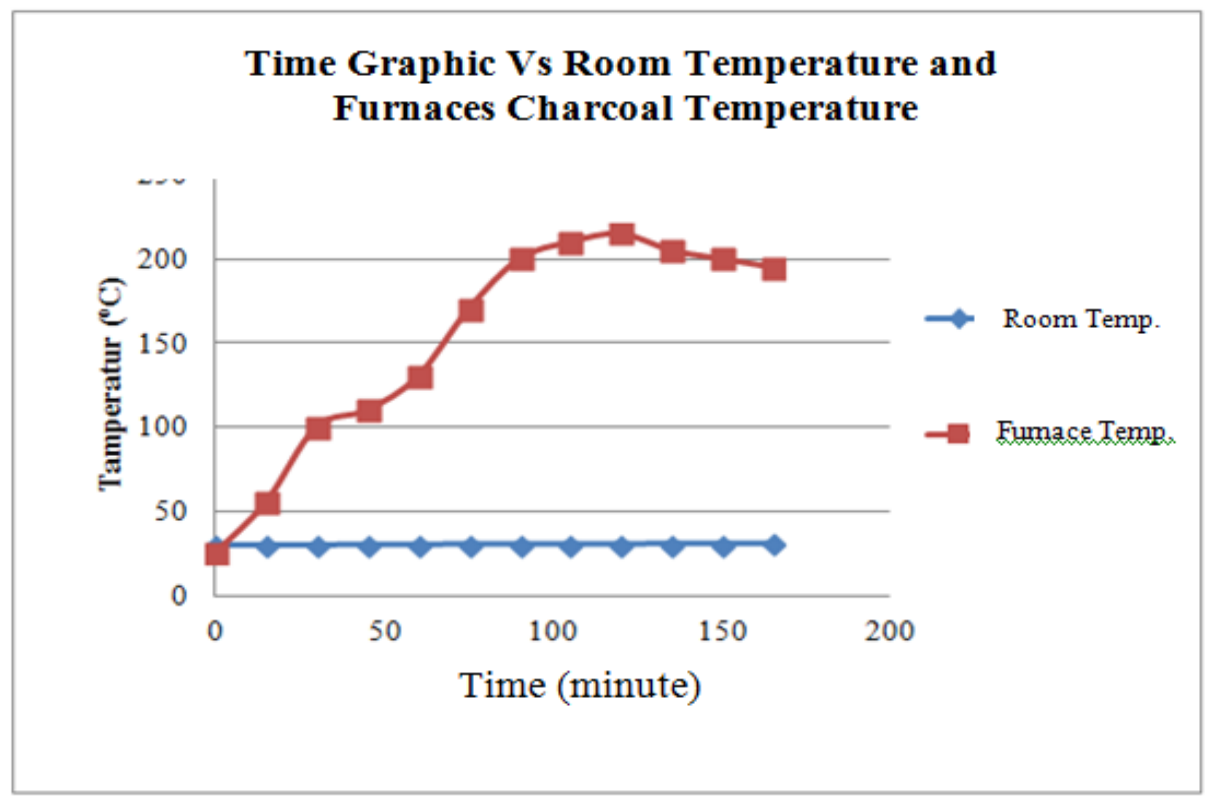

Pic. 10. Time Graphic vs Room Temperature and Furnaces Charcoal Temperature

The combustion process of coconut shell on the charcoal furnace increased the temperature for each multiple time 15 minutes and linier approach and decrease of temperature when the combustion process is completed.

\section{CONCLUSION}

From the results of tests performed, it can be concluded that control system producing charcoal capable of producing charcoal through the process of burning coconut shells through the medium of the furnace with reference to ambient temperature furnace at $200 \mathrm{C}$, obtained the data that the operating time of 150 minutes for the temperature of the room for $30.7 \mathrm{C}$ and the temperature in the furnace at $2000 \mathrm{C}$, data types coconut shell weight ratio before and after the combustion process, obtained by the difference gravity of 14 , $25 \mathrm{~kg}$. In the future the system created can be used for home industries to yield more optimal production resulting from the processing of charcoal produced conventionally.

\section{REFERENCES}

[1] Alexius Luther Ola, Proses Pengolahan Arang Tempurung Kelapa Mmenggunakan Tungku Modifikasi Metode Lubang, Jurnal Penelitian Teknologi Industri Vol. 4 No.2 Desember 2012 : 36-41, ISSN No.2085580X, 2012.

[2] Budiharto, W.; Interfacing Komputer dan Mikrokontroler; Publisher Elex Media Komputindo, Jakarta. 2004.

[3] Dian Artanto, Interaksi Arduino dan LabVIEW, Publisher PT. Elex MediaKomputindo, Jakarta, 2012.

[4] Hendra, Dj. 2007. Teknologi Tepat Guna Pembuatan Arang, Briket Dan Tungku Hemat Energi. Research and Development Centre of Woods Product, Bogor.

[5] J.O Otulana, O.O Oluwele, M.B Adeleke; A Reactor Plant for Activated Carbon Prodduction, Vol.2, pp: (2026), 2016, ISSN 234-7349. Novelty Journals. 
[6] Kaeke, Hilda F.G.; Lumingkewas, Meiske S.Y. 1993. Pembuatan Arang Aktif Dari Tempurung Kelapa Dengan Cara Pemanasan Pada Suhu Tinggi. ScientificMagazine BIMN, (5) 1992/1993: 1-5

[7] Meyti Jeanne Rampe, Bambang Setiaji, Wega Trisunaryanti, Study on Growth of Carbon Crystal from Charcoal of Coconut Shell and PVA, International Journal of Emerging Techology and Advanced Engineering, Vol 6, Issue 1, January 2016, ISSN 22502459, ISO 9001-2008, 2016.
[8] NI-Tutorial 12879 (2011), Top 5 Reasons LabVIEW Makes You More Productive When Using Arduino, www.ni.com

[9] Pohan, Hitles guring. 1998. Pemanfaatan Tempurung Kelapa Untuk Arang Aktif Sebagai Hasil Samping Pengolahan Kopra. Post-harvest Agricultural Research Seminar, Prosiding, Bogor, 1-2 Feb. 1998.

[10] Sudrajat dan S. Soleh. Petunjuk Teknis Pembuatan Arang Aktif. Research and Development Centre of Woods Product and Sosek Forestry, Bogor, 2007. 